\title{
SAFE HAVEN, HEDGE AND DIVERSIFICATION FOR STOCK MARKETS: GOLD VERSUS SILVER
}

\author{
Ana Farinha ${ }^{1}$ \\ Rui Dias ${ }^{2}$ \\ Paula Heliodoro ${ }^{3}$ \\ Paulo Alexandre 4
}

DOI: https://doi.org/10.31410/ITEMA.S.P.2020.67

\begin{abstract}
This paper aims to analyse if whether Gold (Gold Bullion: Zurich) and Silver (Silver Paris Spot E/KG) will be a safe haven for portfolio diversification in the financial markets of Germany (DAX 30), USA (DOW JONES), France (CAC 4 O), Italy (FTSE MID), United Kingdom (FTSE 100), Hong Kong (Hang Seng), China (SHANGHAI SE ASHARE), Japan (NIKKEI 225), in the period between 1 January 2019 to 2 September 2020. In order to perform this analysis where undertaken different approaches to analyse if: (i) the gold and silver market will be a safe haven when financial markets break down? (ii) If so, can market shocks question portfolio diversification? The results suggest 53 pairs of integrated markets (out of 90 possible). Gold and Silver have integrations with each other and with the USA, but the other financial markets integrate with Gold and Silver, namely the US, France, UK, Italy and Hong Kong markets (the latter only with Silver). The China market has a single integration but is integrated by the USA, France, the United Kingdom, Italy, and Germany, which partially rejects the first investigation question. In corroboration, causality tests show 67 causal relationships (out of 90 possible). The Markets of Italy (FTSE MID), the USA (DOW JONES) cause, in the Grangerian sense, all its peers (9 out of 9 possible), while France (CAC 40), the United Kingdom (FTSE 100), Japan (NIKKEI 225), and Germany (DAX 30) cause 8 out of 9. Silver and Gold cause the financial markets 7, and 6 times (out of 9 possible), respectively, while the Hong Kong (Hang Seng) and China (SHANGHAI) markets cause 3 and once, respectively, which validates the second investigation question. Given the high level of integration and shocks between markets, portfolio diversification may be brought into question. These findings also make room for market regulators to take steps to ensure better information among international financial markets.
\end{abstract}

Keywords: Gold, Silver, Hedging, Safe haven, Risk diversification.

\section{INTRODUCTION}

7 he fastest dissemination of the Coronavirus (COVID-19) has caused stress in the financial markets all around the world. The global pandemic of 2020 generated an unprecedented level of risk, causing investors to suffer significant losses, in a short amount of time. The new Coronavirus disease evolved quickly from a provincial health outbreak to a global collapse, affecting the global economy, damaging one-quarter of the global

\footnotetext{
Escola Superior de Ciências Empresarias - Instituto Politécnico de Setúbal, Portugal Escola Superior de Ciências Empresarias - Instituto Politécnico de Setúbal, Portugal \& CEFAGE, Universidade de Évora, Portugal

Escola Superior de Ciências Empresarias - Instituto Politécnico de Setúbal, Portugal Escola Superior de Ciências Empresarias - Instituto Politécnico de Setúbal, Portugal
} 
wealth in less than a month. (Larry, 2020; Ali, Alam, and Rizvi, 2020; Zhang, Hu, and Ji, 2020).

The growing trend of integration and interdependence in international financial markets has increased the probability of risk transmission between markets. In times of agitation, investors should rebalance their portfolios by closing long positions in markets with significant levels of risk. (Dias, da Silva, and Dionísio, 2019; Mohammadpoor and Rezazadeh, 2019; Morales and Gassie, 2014).

The growing uncertainty of the global economy has been passed on to the global financial market, which causes investors to tend to distribute their portfolios from high-risk markets to low-risk markets. From the perspective of investors, and risk managers, gold is regularly regarded as a hedge or safe haven against stock markets, so understanding the relationship between gold and financial markets has relevant implications. (Ma, Yang, Zou, and Liu, 2020; Yamaka and Maneejuk, 2020).

The goal of this paper is to test if whether Gold (Gold Bullion, Zurich) and Silver (Silver Paris Spot E/KG), will be a safe haven for portfolio diversification in financial markets of Germany (DAX 30), ), EUA (DOW JONES), France (CAC 40), Italy (FTSE MID), United Kingdom (FTSE 100), Hong Kong (Hang Seng), China (SHANGHAI SE A SHARE), Japan (NIKKEI 225), in the period between 1 January 2020 to 2 September 2020. In order to perform this analysis, different approaches will be undertaken to analyse the two investigation questions: (i) will the gold and silver market be a safe haven when financial markets break down? (ii) If so, can market shocks question portfolio diversification? The results show that the high level of integration and shocks may question portfolio diversification.

This research adds two contributions to the literature. The first refers to the study of risk diversification in international markets, and the Gold Bullion (Zurich) and Silver (Silver Paris Spot E/KG) markets. Most of the previous studies focused on the correlations or average dependencies between gold and financial market movements, and between gold and currency depreciation. The second contribution relates to the combination of some of the most relevant financial markets in global terms and tests whether the gold and silver market will be a safe haven when these stock markets break down from high levels of risk, particularly during the global pandemic (Covid-19). As far as we know, there are recent studies that have looked at risk diversification, crossing the stock and gold markets, namely the authors, Naeem, Hasan, Arif, Balli, and Shahzad (2020), Hussain Shahzad, Bouri, Roubaud, and Kristoufek (2020), Yamaka and Maneejuk (2020); however, the approach was quite different from the one followed in this paper.

In terms of structure, this paper is organized into 5 sections. Section 1 is represented by the current introduction. Section 2 presents a Literature Review on articles about assets that may be safe ports in portfolio diversification. Section 3 describes the data and methodology. Section 4 contains the results. Finally, section 5 presents the general conclusions of the work.

\section{LITERATURE REVIEW}

Understanding the international connections between financial markets in times of financial crisis is relevant for investors, fund managers, and academics in different respects, particularly on the subject of portfolio diversification. (Kumar, 2017; Sheik and Banu, 2015). 
Balcilar, Hammoudeh, and Asaba (2015), Batten, Ciner, Kosedag, and Lucey (2017), Laily et al. (2017) analysed gold synchronism with certain assets and markets. Balcilar, Hammoudeh, and Asaba (2015) show that gold is a less volatile asset when compared to silver and oil, ensuring its use as a "safe haven asset". Batten, Ciner, Kosedag, and Lucey (2017) evidence the lack of causal relationships between the price of gold and the stock markets analysed. On the other hand, Laily et al. (2017) show a positive relationship between crude oil prices, and the price of gold, and a negative synchronization between inflation rate, GDP, interest rates, and exchange rates.

Tursoy and Faisal (2018), Siddiqui and Roy (2019), D. Huang and Kilic (2019) examined the importance of gold as a safe risk hedging asset. Tursoy and Faisal (2018) show a negative relationship between the price of gold and stock prices and a positive relationship between crude oil and stock prices. Siddiqui and Roy (2019) show that gold is a more effective hedging asset than crude oil for institutional investors in India. D. Huang and Kilic (2019) demonstrate that gold prices fall into recessions, although to a smaller extent than platinum prices.

Balcilar, Demirer, Gupta, and Wohar (2020), Kang, Yoon, Bekiros, and Uddin (2020), Bouri, Shahzad, Roubaud, Kristoufek, and Lucey (2020), Corbet, Larkin, and Lucey (2020), Yamaka and Maneejuk (2020) examined several assets to test whether they are an alternative to stock markets. Balcilar, Demirer, Gupta, and Wohar (2020) show that precious metals cause shocks in stock markets in periods of high volatility. However, treasury bonds present negligible risk in periods of stock stress which implies that these assets would serve as more effective hedges (or safe havens) for investors in international stock markets. Kang, Yoon, Bekiros, and Uddin (2020) investigated the dynamic relationship between Bitcoin and U.S. stocks (S\&P 500), U.S. dollar, treasury bonds and gold futures, evidencing that Bitcoin can be used as a safe haven for investors. Bouri, Shahzad, Roubaud, Kristoufek, and Lucey (2020) compared bitcoin's safe harbour properties, gold and commodity index with stock markets. The authors show that the degree of co-movement between gold and the profitability of the shares affects the VaR level of the portfolio. Specifically, the benefits of diversification vary in frequency of time, with Bitcoin showing superiority over gold and the commodity index. Corbet, Larkin, and Lucey (2020) evidence significant causalities and shocks between China's major stock markets and Bitcoin during the global pandemic (Covid-19), showing reservations about this new financial product in portfolio diversification. Yamaka and Maneejuk (2020) presented significant causalities between gold and the volatility of Asian stock markets during the global financial crisis (2008).

Naeem, Hasan, Arif, Balli, and Shahzad (2020), Hussain Shahzad, Bouri, Roubaud, and Kristoufek (2020), Yamaka and Maneejuk (2020) examined the synchronization between the stock markets with oil, gold and Bitcoin. Naeem, Hasan, Arif, Balli, and Shahzad (2020) show that the global financial crisis of 2008 accentuated the shocks between BRIC stock markets with oil and gold. Hussain Shahzad, Bouri, Roubaud, and Kristoufek (2020) demonstrate that gold and Bitcoin are safe ports but have distinct hedging characteristics. Gold is an undisputed haven and protection in the G7 stock markets, while Bitcoin takes on these two functions in Canada. They suggest that the diversification benefits offered by gold to capital investments in the G7 markets are comparatively higher and more stable than Bitcoin. Yamaka and Maneejuk (2020) evidence the existence of significant causalities between gold shocks and volatilities in Asian stock markets. The authors show strong correlations between the South Korean stock markets and India, and the gold market, during the global financial crisis when compared to the pre and post-crisis periods. Additionally, there are indications of the existence of contagion effects between the gold market and the stock markets analysed. 
In summary, this work aims to contribute to the provision of information to investors and regulators in international stock markets, where individual and institutional investors seek diversification benefits. Therefore, the context of this work is to examine the integration and shocks between the stock markets under analysis and the prices of Gold and Silver, to understand whether these commodities will be a safe haven in the period of the global pandemic (Covid-19).

\section{METHODOLOGY}

\section{DATA}

The data analysed are the index prices from the stock markets of Germany (DAX 30), EUA (DOW JONES), France (CAC 40), Italy (FTSE MID), United Kingdom (FTSE 100), Hong Kong (Hang Seng), China (SHANGHAI SE A SHARE), Japan (NIKKEI 225), and gold prices (Gold Bullion: Zurich) and Silver(Silver Paris Spot E/KG), between the period of 1 January 2019 to 2 de September 2020. The quotations are daily and were obtained from the Thomson Reuters platform. The quotes are in local currency to mitigate distortions in exchange rates.

Table 1. The name of countries and their indices used in this paper

\begin{tabular}{|l|c|}
\hline \multicolumn{1}{|c|}{ Country } & Index \\
\hline Germany & DAX 30 \\
\hline USA & DOW JONES \\
\hline France & CAC 40 \\
\hline Italy & FTSE MID \\
\hline United Kingdom & FTSE 100 \\
\hline Hong Kong & HANG SENG \\
\hline China & SHANGHAI SE A SHARE \\
\hline Japan & NIKKEI 225 \\
\hline Gold & Gold Bullion (Zurich) kg (995) CHF \\
\hline Silver & Silver Paris Spot E/KG \\
\hline
\end{tabular}

Source: Own elaboration.

\section{METHODOLOGY}

The development of the research took place along several stages. The characterization of the sample used was performed through descriptive statistics, the adherence test of Jarque and Bera (1980), and the quantile charts. In order to assess the stationarity of the time series, we will use the ADF tests (Dickey and Fuller, 1981) and PP (Perron and Phillips, 1988). For the verification of integration or segmentation between the financial markets analysed, we'll use the methodology of Gregory and Hansen (1996) because we are looking at a very troubled period in the financial markets. Additionally, the reason why standard cointegration tests such as Engle and Granger (1987) and Johansen (1988), are not appropriate to test the cointegration with regime change that such tests assume that the cointegration vector is invariant in time.

To examine the clashes between markets we will use the VAR Granger Causality/Block Exogeneity Wald Tests model, which employs Wald's statistics, which tests whether the null hypothesis that the coefficients of the out-of-date endogenous variables of the variable "cause" are null or not "cause" in the Grangerian sense of the dependent variable. However, the result of this test has a high sensitivity to the number of lags considered in the model, so the first concern is to conveniently estimate this value, in order to reach robust evidence (Gujarati, 
2004). To determine the number of lags to include in causality tests, we will use the Final Prediction Error (FPE) and Akaike information criterion (AIC) criteria to validate the robustness of the model we will estimate the VAR Residual Serial Correlation LM Tests.

\section{RESULTS}

Figure 1 shows the evolution of the financial markets, at levels, between 1 January of 2019 to 2 September 2020, being this a period of great complexity, due to the global pandemic outbreak (Covid-19). Most of the markets reveal structural breakdowns between February and March of 2020.

Figure 1: Evolution, in levels, of the ten financial markets, between the period of 1 January 2019 to 2 September 2020

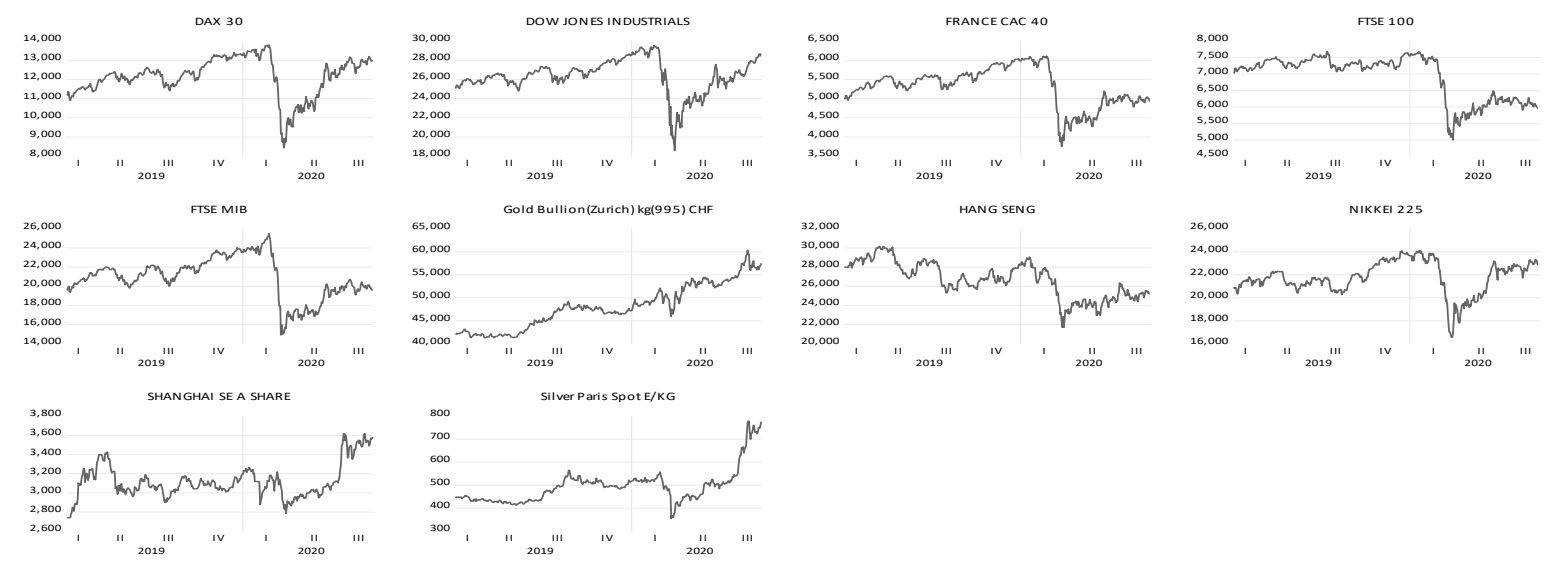

Source: Own elaboration.

Figure 2 shows the evolution, in $\%$ of the differences, of the 10 financial markets under analysis. In all series, a relatively high dispersion around the mean is noted, as well as a relatively synchronized behaviour between the data series. Through graphical analysis, high volatility is observed, especially in February, March, and April 2020.

Figure 2. Evolution, in $\%$ of the differences, of the 10 financial markets, between the period of 1 January 2019 to 2 September 2020.

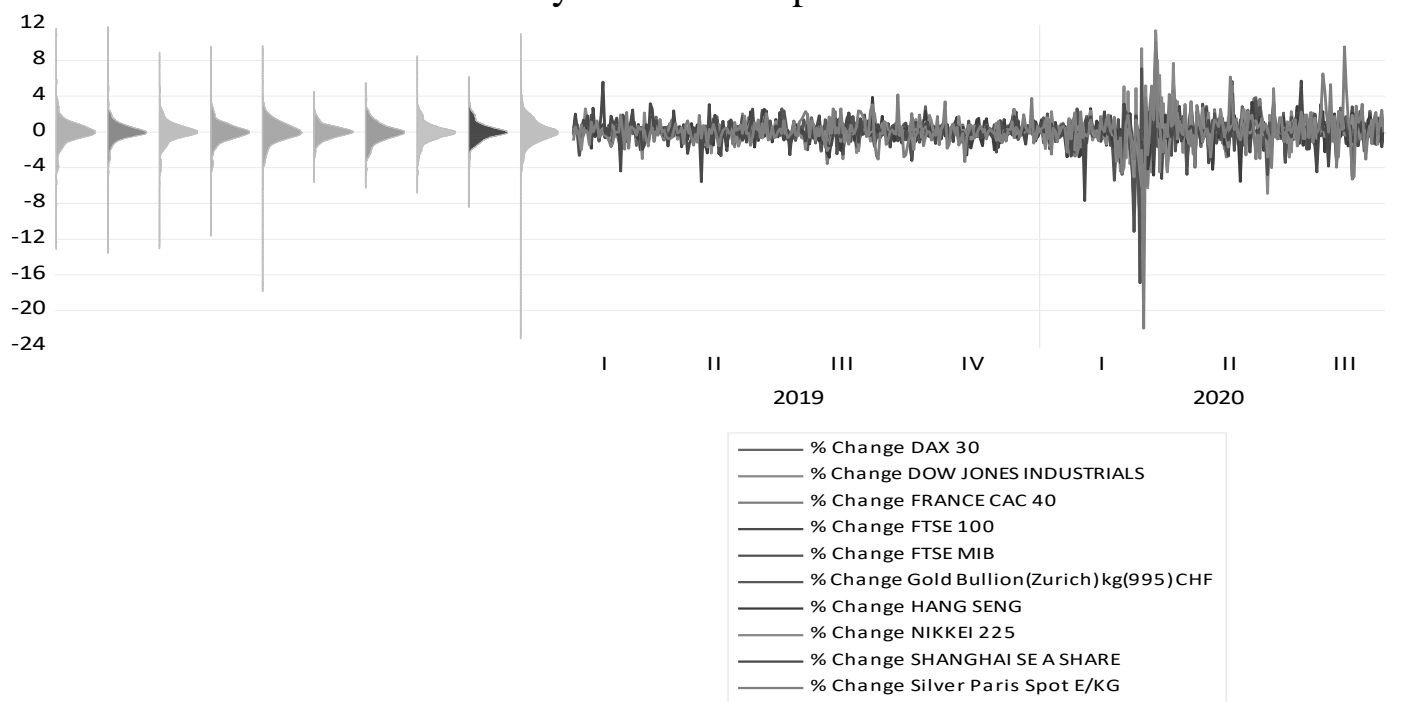

Source: Own elaboration. 
Tables 2 and 3 show the main descriptive statistics from the financial markets analysed. The profitability of stock indices has positive daily averages, except for the Markets of France (CAC 40), The United Kingdom (FTSE 100), and Hong Kong (HANG SENG). However, all the series showed signs of deviation from the hypothesis of normality, considering the coefficients of skewness and kurtosis. The asymmetry characteristics are negative, especially in silver prices. Additionally, the coefficients of skewness and kurtosis are statistically different from those in a normal distribution, these indices are corroborated by the Jarque-Bera adherence test.

Table 2: Descriptive statistics, in profitability, of the 10 financial markets, between the period of 1 January 2019 to 2 September 2020.

\begin{tabular}{|c|c|c|c|c|c|}
\hline & DAX 30 & DOW JONES & CAC40 & FTSE 100 & FTSE MIB \\
\hline Mean & 0.000359 & 0.000323 & $-3.94 \mathrm{E}-05$ & -0.000435 & $2.25 \mathrm{E}-06$ \\
\hline Std. Dev. & 0.016387 & 0.018343 & 0.016123 & 0.014549 & 0.017947 \\
\hline Skewness & -1.160567 & -1.060573 & -1.728236 & -1.407132 & -3.292874 \\
\hline Kurtosis & 18.42201 & 19.26823 & 17.63492 & 17.46935 & 35.74753 \\
\hline Jarque-Bera & $4195.652 * * *$ & $4642.918 * * *$ & $3900.710 * * *$ & $3748.119 * * *$ & $19247.08 * * *$ \\
\hline Sum & 0.148781 & 0.133574 & -0.016302 & -0.180295 & 0.000932 \\
\hline Sum Sq. Dev. & 0.110904 & 0.138953 & 0.107359 & 0.087423 & 0.133021 \\
\hline Observations & 414 & 414 & 414 & 414 & 414 \\
\hline
\end{tabular}

Source: Own elaboration.

Notes: ***.**. *. represent significance at $1 \% .5 \%$ and $10 \%$, respectively.

Table 3. Descriptive statistics, in profitability, of the 10 financial markets, between the period of 1 January 2019 to 2 September 2020.

\begin{tabular}{|l|c|c|c|c|c|}
\hline & GOLD & HANG SENG & NIKKEI 225 & SHANGHAI & SILVER \\
\hline Mean & 0.000745 & -0.000256 & 0.000270 & 0.000636 & 0.001306 \\
\hline Std. Dev. & 0.009279 & 0.012770 & 0.013390 & 0.012568 & 0.020734 \\
\hline Skewness & -0.449500 & -0.385542 & 0.207371 & -0.767970 & -3.731415 \\
\hline Kurtosis & 8.868926 & 5.879456 & 9.485668 & 10.07067 & 54.52105 \\
\hline Jarque-Bera & $608.1056 * * *$ & $153.2807 * * *$ & $728.5692 * * *$ & $903.0985 * * *$ & $46749.44 * * *$ \\
\hline Sum & 0.308557 & -0.106060 & 0.111788 & 0.263511 & 0.540774 \\
\hline Sum Sq. Dev. & 0.035560 & 0.067350 & 0.074046 & 0.065233 & 0.177553 \\
\hline Observations & 414 & 414 & 414 & 414 & 414 \\
\hline
\end{tabular}

Source: Own elaboration.

Notes: ***.**.*. represent significance at $1 \% .5 \%$ and $10 \%$, respectively.

The quantile charts demonstrate that the distribution of profitability rates is leptokurtic and asymmetric or skewed. The distribution is leptokurtic because the graph is shaped like "S", on the $45^{\circ}$ line, and is asymmetric because the " $\mathrm{S}$ " is not symmetrical on the line, evidencing the existence of nonlinear relationships (see Figure 3).

The results from the stationarity tests, through the ADF tests (Dickey and Fuller, 1981), and PP (Perron and Phillips, 1988), reveal that the temporal series analysed are stationarity, in profitability, fundamental presupposition for estimating the model VAR Granger Causality/Block Exogeneity Wald Tests (attachments A, B e C). 
Figure 3. Quantile charts of profitability rates, from the financial markets under analysis, between the period of 1 January 2019 to 2 September 2020
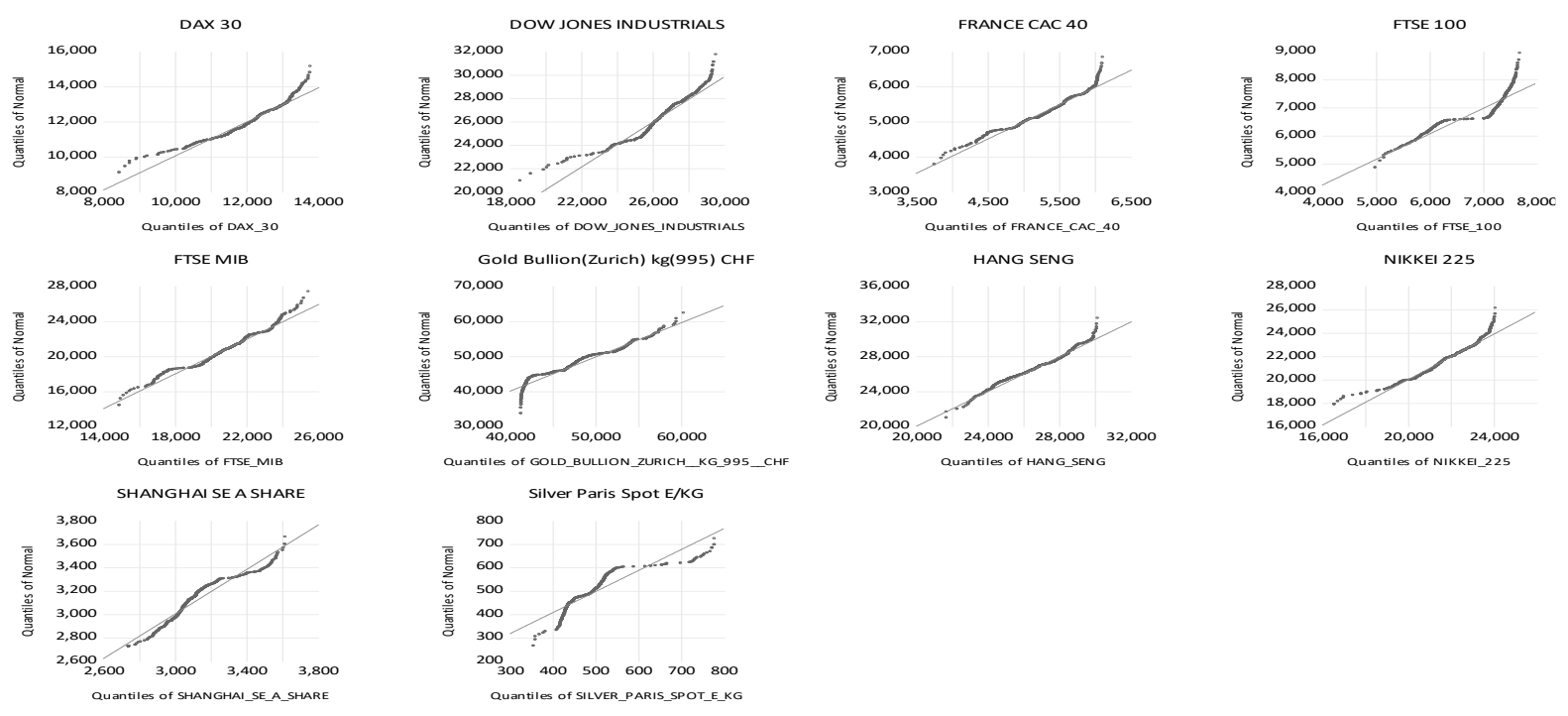

Source: Own elaboration

In Table 4 are the results from the Gregory-Hansen integration test, with structure breakage, and we found 53 pairs of integrated markets (out of 90 possible); we also saw that the structural breakdowns occur, mostly, in March 2020. The UK market (FTSE 100) has 9 integrations (out of 9 possible), while the US (DOW JONES), France (CAC 40), Italy (FTSE MID) markets show 8 integrations. The Hong Kong (HANG SENG), Japan (NIKKEI 225), and Germany markets show 5 integrations, Gold and Silver have 2 integrations. The China market (SHANGHAI) has a single integration with the United Kingdom (FTSE 100). In response to the first investigation question, gold and silver prices have integrations with each other and with the US, but the other financial markets integrate with Gold and Silver, namely the US, France, UK, Italy, and Hong Kong markets (the latter only with Silver). The China market has a single integration, but is integrated by the USA, France, THE UNITED KINGDOM, Italy, and Germany; these findings show that portfolio diversification could be put into question due to the high level of integration between the stock markets and Gold and Silver.

Table 4. Gregory-Hansen tests, between the period of 1 January 2019 to 2 September 2020.

\begin{tabular}{|l|c|c|c|c|c|}
\hline \multicolumn{1}{|c|}{ Markets } & t-statistic & Method & Lags & Break Date & Results \\
\hline GOLD / SILVER & $-6.75^{* * *}$ & Regime & 0 & $17 / 03 / 2020$ & Integration \\
\hline GOLD / DJ & $-4.81^{*}$ & Regime & 0 & $27 / 02 / 2020$ & Integration \\
\hline SILVER / GOLD & $-5.63^{* * *}$ & Regime & 3 & $18 / 03 / 2020$ & Integration \\
\hline SILVER / DJ & $-5.81^{* * *}$ & Regime & 3 & $03 / 06 / 2020$ & Integration \\
\hline DJ / GOLD & $-5.21^{* *}$ & Regime & 2 & $12 / 03 / 2020$ & Integration \\
\hline DJ / SILVER & $-53.43^{* *}$ & Trend & 2 & $28 / 02 / 2020$ & Integration \\
\hline DJ / CAC 40 & $-53.47 * *$ & Regime & 4 & $04 / 03 / 2020$ & Integration \\
\hline DJ / FTSE MID & $-54.38^{* *}$ & Trend & 2 & $10 / 04 / 2020$ & Integration \\
\hline DJ / HANG SENG & $-56.10^{* *}$ & Trend & 2 & $28 / 02 / 2020$ & Integration \\
\hline DJ / NIKKEI 225 & $-6.76^{* * *}$ & Trend & 1 & $12 / 03 / 2020$ & Integration \\
\hline DJ / DAX 30 & $-62.15^{* * *}$ & Trend & 1 & $12 / 03 / 2020$ & Integration \\
\hline DJ / SHANGHAI & $-5.48^{* * *}$ & Trend & 2 & $28 / 02 / 2020$ & Integration \\
\hline
\end{tabular}




\begin{tabular}{|c|c|c|c|c|c|}
\hline CAC 40 / GOLD & $-6.89 * * *$ & Trend & 1 & $02 / 03 / 2020$ & Integration \\
\hline CAC 40 / SILVER & $-6.39 * * *$ & Trend & 1 & $02 / 03 / 2020$ & Integration \\
\hline CAC $40 /$ DJ & $-6.18 * * *$ & Trend & 1 & $03 / 03 / 2020$ & Integration \\
\hline CAC 40 / FTSE MID & $-6.52 * * *$ & Regime & 4 & $30 / 01 / 2020$ & Integration \\
\hline CAC 40 / HANG SENG & $-5.49 * * *$ & Regime & 0 & $29 / 07 / 2019$ & Integration \\
\hline CAC 40 / NIKKEI 225 & $-6.22 * * *$ & Regime & 1 & $10 / 03 / 2020$ & Integration \\
\hline CAC 40 / DAX 30 & $-6.55 * * *$ & Regime & 2 & $03 / 03 / 2020$ & Integration \\
\hline CAC 40 / SHANGHAI & $-7.69 * * *$ & Trend & 2 & $02 / 03 / 2020$ & Integration \\
\hline FTSE 100 / GOLD & $-6.63 * * *$ & Trend & 1 & $02 / 03 / 2020$ & Integration \\
\hline FTSE 100 / SILVER & $-6.59 * * *$ & Trend & 1 & $02 / 03 / 2020$ & Integration \\
\hline FTSE 100 / DJ & $-5.47 * * *$ & Trend & 0 & $02 / 03 / 2020$ & Integration \\
\hline FTSE 100 / CAC 40 & $-5.09 * *$ & Regime & 0 & $02 / 03 / 2020$ & Integration \\
\hline FTSE 100 / FTSE MID & $-5.37 * *$ & Regime & 0 & $02 / 03 / 2020$ & Integration \\
\hline FTSE 100 / HANG SENG & $-5.56 * * *$ & Regime & 0 & $02 / 03 / 2020$ & Integration \\
\hline FTSE 100 / NIKKEI 225 & $-6.99 * * *$ & Regime & 0 & $02 / 03 / 2020$ & Integration \\
\hline FTSE 100 / DAX 30 & $-6.82 * * *$ & Regime & 1 & $02 / 03 / 2020$ & Integration \\
\hline FTSE 100 / SHANGHAI & $-6.46 * * *$ & Regime & 1 & $02 / 03 / 2020$ & Integration \\
\hline FTSE MID / GOLD & $-5.68 * * *$ & Trend & 0 & $03 / 03 / 2020$ & Integration \\
\hline FTSE MID / SILVER & $-5.75 * * *$ & Trend & 0 & $03 / 03 / 2020$ & Integration \\
\hline FTSE MID / DJ & $-5.41 * *$ & Trend & 4 & $04 / 03 / 2020$ & Integration \\
\hline FTSE MID / CAC 40 & $-6.64 * * *$ & Trend & 4 & $30 / 01 / 2020$ & Integration \\
\hline FTSE MID / HANG SENG & $-5.53 * * *$ & Regime & 0 & $30 / 07 / 2019$ & Integration \\
\hline FTSE MID / NIKKEI 225 & $-6.24 * * *$ & Regime & 1 & $10 / 04 / 2020$ & Integration \\
\hline FTSE MID / DAX 30 & $-48.20 * * *$ & Trend & 5 & $04 / 03 / 2020$ & Integration \\
\hline FTSE MID / SHANGHAI & $-6.75 * * *$ & Trend & 3 & $02 / 03 / 2020$ & Integration \\
\hline HANG SENG / SILVER & $-4.70 *$ & Regime & 1 & $03 / 03 / 2020$ & Integration \\
\hline HANG SENG / CAC 40 & $-5.09 * *$ & Trend & 0 & $02 / 03 / 2020$ & Integration \\
\hline HANG SENG / FTSE 100 & $-4.88 *$ & Trend & 0 & $21 / 05 / 2020$ & Integration \\
\hline HANG SENG / FTSE MID & $-5.66 * * *$ & Trend & 0 & $02 / 03 / 2020$ & Integration \\
\hline HANG SENG / DAX 30 & $-5.08 * *$ & Trend & 0 & $19 / 12 / 2020$ & Integration \\
\hline NIKKEI 225 / DJ & $-6.09 * * *$ & Regime & 1 & $26 / 05 / 2020$ & Integration \\
\hline NIKKEI 225 / CAC 40 & $-6.71 * * *$ & Regime & 1 & $10 / 03 / 2020$ & Integration \\
\hline NIKKEI 225 / FTSE 100 & $-50.14 * *$ & Trend & 1 & $16 / 05 / 2019$ & Integration \\
\hline NIKKEI 225 / FTSE MID & $-5.84 * * *$ & Trend & 2 & $10 / 03 / 2020$ & Integration \\
\hline NIKKEI 225 / DAX 30 & $-6.23 * * *$ & Regime & 1 & $17 / 09 / 2019$ & Integration \\
\hline DAX $30 /$ DJ & $-5.39 * *$ & Regime & 1 & $28 / 05 / 2020$ & Integration \\
\hline DAX 30 / CAC 40 & $-5.70 * * *$ & Regime & 0 & $04 / 03 / 2020$ & Integration \\
\hline DAX 30 / FTSE MID & $-4.92 *$ & Regime & 0 & $04 / 03 / 2020$ & Integration \\
\hline DAX 30 / NIKKEI 225 & $-6.19 * * *$ & Trend & 1 & 03/05/2019 & Integration \\
\hline DAX 30 / SHANGHAI & $-5.04 * *$ & Trend & 2 & $02 / 03 / 2020$ & Integration \\
\hline SHANGHAI / FTSE 100 & $-5.02 * *$ & Regime & 5 & $05 / 06 / 2020$ & Integration \\
\hline
\end{tabular}

Source: Own elaboration.

Notes: ***.**.*. represent significance at $1 \% .5 \%$ and $10 \%$, respectively. 
To analyse the significance of causal relationships between financial markets under analysis, we applied the VAR Granger Causality/Block Exogeneity Wald Tests. To determine the number of lags to be included in causality tests, we used the Final prediction error (FPE) criteria and AIC (Akaike information criterion) that suggest 4 lags. A smaller number of lags increases the degrees of freedom; a greater number of lags decreases the problems of autocorrelation (see Table 5).

Table 5. VAR Lag Order Selection Criteria

\begin{tabular}{|c|c|c|c|c|c|c|}
\hline Lag & LogL & LR & FPE & AIC & SC & HQ \\
\hline $\mathbf{4}$ & 13686.73 & 224.7519 & $\mathbf{1 . 3 6 e - 4 1} *$ & $\mathbf{- 6 5 . 7 2 6 3 9} *$ & -61.66555 & -64.11888 \\
\hline
\end{tabular}

Source: Own elaboration.

Note: * indicates lag order selected by the criterion.

In Table 6 is possible to check the results of VAR Residual Serial Correlation LM Tests, we estimate a VAR with 4 lags, and verified the existence of autocorrelation in the residues (5 lags). To eliminate the correlation in series we estimated a VAR with 6 lags, and then performed the autocorrelation test to 7 lags, the null hypothesis was not rejected, which corroborates that the present model is a robust estimate.

Table 6. VAR Residual Serial Correlation LM Tests

\begin{tabular}{|c|c|c|c|c|c|c|}
\hline Lag & LRE* stat & df & Prob. & Rao F-stat & df & Prob. \\
\hline $\mathbf{7}$ & $\mathbf{9 3 . 7 1 5 1 0}$ & $\mathbf{1 0 0}$ & $\mathbf{0 . 6 5 7 9}$ & $\mathbf{0 . 9 3 6 1 8 1}$ & $\mathbf{( 1 0 0 , 2 3 6 0 . 2 )}$ & $\mathbf{0 . 6 5 8 2}$ \\
\hline
\end{tabular}

Source: Own elaboration.

Table 7. Granger Causality Testes / Block Exogeneity Wald Tests, between the period of 1 January 2019 to 2 September 2020.

\begin{tabular}{|c|c|c|c|c|c|c|c|c|c|c|}
\hline & GOLD & $\begin{array}{c}\text { SILVE } \\
\text { R }\end{array}$ & DJ & CAC 40 & $\begin{array}{c}\text { FTSE } \\
100\end{array}$ & $\begin{array}{l}\text { FTSE } \\
\text { MID }\end{array}$ & $\begin{array}{c}\text { HANG } \\
\text { SENG }\end{array}$ & $\begin{array}{c}\text { NIKKEI } \\
225\end{array}$ & DAX 30 & $\begin{array}{c}\text { SHANG } \\
\text { HAI }\end{array}$ \\
\hline GOLD & $\begin{array}{c}* * * * * * * \\
*\end{array}$ & $\begin{array}{c}5.51(6) \\
* * *\end{array}$ & $\begin{array}{c}3.66(6) \\
* * *\end{array}$ & $\begin{array}{c}6.54(6) \\
* * *\end{array}$ & $\begin{array}{c}4.67(6) \\
* * *\end{array}$ & $\begin{array}{c}7.85(6) \\
* * *\end{array}$ & $\begin{array}{c}2.23(6) \\
* *\end{array}$ & $\begin{array}{c}2.35(6) \\
* *\end{array}$ & $\begin{array}{c}6.43(6) \\
* * *\end{array}$ & $0.50(6)$ \\
\hline SILVER & $\begin{array}{c}17.78(6) \\
* * *\end{array}$ & $\begin{array}{c}* * * * * * \\
* *\end{array}$ & $\begin{array}{c}9.83(6) \\
* * *\end{array}$ & $\begin{array}{c}10.07(6) \\
* * *\end{array}$ & $\begin{array}{c}10.29(6) \\
* * *\end{array}$ & $\begin{array}{c}17.69(6) \\
* * *\end{array}$ & $1.01(6)$ & $\begin{array}{c}3.06(6) \\
* * *\end{array}$ & $\begin{array}{c}9.16(6) \\
* * *\end{array}$ & $0.94(6)$ \\
\hline DJ & $\begin{array}{c}4.52(6) \\
* * *\end{array}$ & $\begin{array}{c}4.92(6) \\
* * *\end{array}$ & $\begin{array}{c}* * * * * * * \\
*\end{array}$ & $\begin{array}{c}9.86(6) \\
* * *\end{array}$ & $\begin{array}{c}4.28(6) \\
* * *\end{array}$ & $\begin{array}{c}14.73(6) \\
* * *\end{array}$ & $1.40(6)$ & $\begin{array}{c}6.16(6) \\
* * *\end{array}$ & $\begin{array}{c}10.75(6) \\
* * *\end{array}$ & $0.83(6)$ \\
\hline CAC 40 & $2.01(6)^{*}$ & $\begin{array}{c}3.93(6) \\
* * *\end{array}$ & $\begin{array}{c}11.52(6) \\
* * *\end{array}$ & $\begin{array}{c}* * * * * * * \\
*\end{array}$ & $\begin{array}{c}3.62(6) \\
* * *\end{array}$ & $\begin{array}{c}7.97(6) \\
* * *\end{array}$ & $1.49(6)$ & $\begin{array}{c}3.86(6) \\
* * *\end{array}$ & $1.08(6)$ & $0.75(6)$ \\
\hline FTSE 100 & $\begin{array}{c}2.26(6) \\
* *\end{array}$ & $\begin{array}{c}5.20(6) \\
* * *\end{array}$ & $\begin{array}{c}7.31(6) \\
* * *\end{array}$ & $\begin{array}{c}5.61(6) \\
* * *\end{array}$ & $\begin{array}{c}* * * * * * * \\
*\end{array}$ & $\begin{array}{c}7.03(6) \\
* * *\end{array}$ & $0.51(6)$ & $\begin{array}{c}4.53(6) \\
* * *\end{array}$ & $\begin{array}{c}3.54(6) \\
* * *\end{array}$ & $0.33(6)$ \\
\hline $\begin{array}{l}\text { FTSE } \\
\text { MID }\end{array}$ & $1.43(6)$ & $1.48(6)$ & $\begin{array}{c}8.75(6) \\
* * *\end{array}$ & $1.51(6)$ & $\begin{array}{c}2.21(6) \\
* *\end{array}$ & $\begin{array}{c}* * * * * * * \\
*\end{array}$ & $1.60(6)$ & $\begin{array}{c}3.03(6) \\
* * *\end{array}$ & $1.84(6)^{*}$ & $1.09(6)$ \\
\hline $\begin{array}{c}\text { HANG } \\
\text { SENG }\end{array}$ & $\begin{array}{c}2.32(6) \\
* *\end{array}$ & $\begin{array}{c}4.98(6) \\
* * *\end{array}$ & $\begin{array}{c}10.92(6) \\
* * *\end{array}$ & $\begin{array}{c}5.32(6) \\
* * *\end{array}$ & $\begin{array}{c}4.74(6) \\
* * *\end{array}$ & $\begin{array}{c}8.63(6) \\
* * *\end{array}$ & $* * * * * * * *$ & $\begin{array}{c}6.01(6) \\
* * *\end{array}$ & $\begin{array}{c}5.73(6) \\
* * *\end{array}$ & $0.45(6)$ \\
\hline $\begin{array}{c}\text { NIKKEI } \\
225\end{array}$ & $\begin{array}{c}2.22(6) \\
* *\end{array}$ & $\begin{array}{c}2.83(6) \\
* *\end{array}$ & $\begin{array}{c}11.16(6) \\
* * *\end{array}$ & $\begin{array}{c}19.87(6) \\
* * *\end{array}$ & $\begin{array}{c}10.99(6) \\
* * *\end{array}$ & $\begin{array}{c}19.94(6) \\
* * *\end{array}$ & $\begin{array}{c}4.51(6) \\
* * *\end{array}$ & $\begin{array}{c}* * * * * * * \\
*\end{array}$ & $\begin{array}{c}24.17(6) \\
* * *\end{array}$ & $1.92(6)^{*}$ \\
\hline DAX 30 & $1.46(6)$ & $\begin{array}{c}4.95(6) \\
* * *\end{array}$ & $\begin{array}{c}10.13(6) \\
* * *\end{array}$ & $\begin{array}{c}2.43(6) \\
* *\end{array}$ & $\begin{array}{c}3.46(6) \\
* * *\end{array}$ & $\begin{array}{c}7.24(6) \\
* * *\end{array}$ & $1.18(6)$ & $\begin{array}{c}2.99(6) \\
* * *\end{array}$ & $\begin{array}{c}* * * * * * * \\
*\end{array}$ & $0.65(6)$ \\
\hline $\begin{array}{c}\text { SHANGH } \\
\text { AI }\end{array}$ & $0.95(6)$ & $1.78(6)$ & $\begin{array}{c}2.54(6) \\
* *\end{array}$ & $\begin{array}{c}2.82(6) \\
* *\end{array}$ & $1.64(6)$ & $\begin{array}{c}3.51(6) \\
* * *\end{array}$ & $\begin{array}{c}3.52(6) \\
* * *\end{array}$ & $1.03(6)$ & $\begin{array}{c}2.32(6) \\
* *\end{array}$ & $\begin{array}{c}* * * * * * * \\
*\end{array}$ \\
\hline
\end{tabular}

Source: Own elaboration.

Notes: Column markets "cause" online markets. The lateral values in parentheses refer to lags. ***.**.*. represent significance at $1 \% .5 \%$ and $10 \%$, respectively.

The results of Granger's causality tests for the financial markets under analysis are shown in Table 7. The causality tests show 67 causal relationships (out of 90 possible). The Markets of Italy (FTSE MID), the USA (DOW JONES) cause, in the Grangerian sense, all its peers (9 out 
of 9 possible), while France (CAC 40), the United Kingdom (FTSE 100), Japan (NIKKEI 225), and Germany (DAX 30) cause 8 out of 9. Silver and Gold cause the financial markets 7, and 6 times (out of 9 possible), respectively, while the Hong Kong (Hang Seng) and China (SHANGHAI) markets cause for 3 and once, respectively. The caused markets in the Grangerian sense are the stock indices NIKKEI 225 (9), HANG SENG (8), DOW JONES (7) FTSE 100 (7), CAC 40 (6), DAX 30 (6), SHANGHAI (5), FTSE MID (4), while Gold and Silver are caused by 8 and 7, respectively. These results show that the Gold and Silver market are not a safe haven, and they are not an alternative to portfolio diversification in these stock markets. These findings are in line with the evidence presented by the authors Yarovaya and Lau (2016), Diaz, Molero, and Perez de Gracia (2016), Ferreira, Dionísio and Movahed (2017) show significant movements in various financial markets, which calls into question portfolio diversification.

\section{CONCLUSION}

The general conclusion to be retained and, supported by the results obtained, through the tests carried out with econometric and mathematical models, demonstrate that the global pandemic has a significant impact on the memory properties of the markets analysed. The results indicate that markets have very significant integrations and causalities, i.e. Gold and Silver do not function as safe havens to portfolio diversification in these stock markets. These findings also make room for market regulators to take steps to ensure better information among international financial markets. In conclusion, we consider that investors should diversify their portfolios, and invest in less risky markets, to mitigate risk and improve the efficiency of their portfolios.

\section{REFERENCES}

Balcilar, M., Demirer, R., Gupta, R., \& Wohar, M. E. (2020). The effect of global and regional stock market shocks on safe haven assets. Structural Change and Economic Dynamics. https://doi.org/10.1016/j.strueco.2020.04.004

Balcilar, M., Hammoudeh, S., \& Asaba, N. A. F. (2015). A regime-dependent assessment of the information transmission dynamics between oil prices, precious metal prices and exchange rates. International Review of Economics and Finance. https://doi.org/10.1016/j.iref.2015.02.005

Batten, J. A., Ciner, C., Kosedag, A., \& Lucey, B. M. (2017). Is the price of gold to gold mining stocks asymmetric? Economic Modelling. https://doi.org/10.1016/j.econmod.2016.10.007

Bouri, E., Shahzad, S. J. H., Roubaud, D., Kristoufek, L., \& Lucey, B. (2020). Bitcoin, gold, and commodities as safe havens for stocks: New insight through wavelet analysis. Quarterly Review of Economics and Finance. https://doi.org/10.1016/j.qref.2020.03.004

Corbet, S., Larkin, C., \& Lucey, B. (2020). The contagion effects of the COVID-19 pandemic: Evidence from gold and cryptocurrencies. Finance Research Letters. https://doi.org/10.1016/j.frl.2020.101554

Dias, R., da Silva, J. V., \& Dionísio, A. (2019). Financial markets of the LAC region: Does the crisis influence the financial integration? International Review of Financial Analysis. https://doi.org/10.1016/j.irfa.2019.02.008

Diaz, E. M., Molero, J. C., \& Perez de Gracia, F. (2016). Oil price volatility and stock returns in the G7 economies. Energy Economics. https://doi.org/10.1016/j.eneco.2016.01.002

Dickey, D., \& Fuller, W. (1981). Likelihood ratio statistics for autoregressive time series with a unit root. Econometrica, 49(4), 1057-1072. https://doi.org/10.2307/1912517

Engle, R. F., \& Granger, C. W. J. (1987). Co-Integration and Error Correction: Representation, 
Estimation, and Testing. Econometrica, 55(2), 251. https://doi.org/10.2307/1913236

Ferreira, P., Dionísio, A., \& Movahed, S. M. S. (2017). Assessment of 48 Stock markets using adaptive multifractal approach. Physica A: Statistical Mechanics and Its Applications, 486, 730-750. https://doi.org/10.1016/j.physa.2017.05.046

Gregory, A. W., \& Hansen, B. E. (1996). Residual-based tests for cointegration in models with regime shifts. Journal of Econometrics, 70(1), 99-126. https://doi.org/10.1016/03044076(69)41685-7

Gujarati, D. N. (2004). Basic Econometrics. New York. https://doi.org/10.1126/science.1186874

Huang, D., \& Kilic, M. (2019). Gold, platinum, and expected stock returns. Journal of Financial Economics. https://doi.org/10.1016/j.jfineco.2018.11.004

Hussain Shahzad, S. J., Bouri, E., Roubaud, D., \& Kristoufek, L. (2020). Safe haven, hedge and diversification for G7 stock markets: Gold versus bitcoin. Economic Modelling. https://doi.org/10.1016/j.econmod.2019.07.023

Jarque, C. M., \& Bera, A. K. (1980). Efficient tests for normality, homoscedasticity and serial independence of regression residuals. Economics Letters, 6(3), 255-259. https://doi.org/10.1016/0165-1765(80)90024-5

Johansen, S. (1988). Statistical Analysis of Cointegrated Vectors. Journal of Economic Dynamics and Control, 12(2-3), 231-254.

Kang, S. H., Yoon, S. M., Bekiros, S., \& Uddin, G. S. (2020). Bitcoin as Hedge or Safe Haven: Evidence from Stock, Currency, Bond and Derivatives Markets. Computational Economics. https://doi.org/10.1007/s10614-019-09935-6

Kumar, S. (2017). What determines the gold inflation relation in the long-run? Studies in Economics and Finance. https://doi.org/10.1108/SEF-04-2016-0084

Laily, S., Hashim, M., Ramlan, H., Huda, N., Razali, A., Zaidah, N., \& Nordin, M. (2017). Macroeconomic Variables Affecting the Volatility of Gold Price. Journal of Global Business and Social Entrepreneurship (GBSE).

Larry, C. (2020). Coronavirus' impact on financial markets | Refinitiv. Perspectives. Refinitiv.

Ma, X., Yang, R., Zou, D., \& Liu, R. (2020). Measuring extreme risk of sustainable financial system using GJR-GARCH model trading data-based. International Journal of Information Management, 50(January 2019), 526-537. https://doi.org/10.1016/j.ijinfomgt. International Journal of Information Management. https://doi.org/10.1016/j.ijinfomgt.2018.12.013

Mohammadpoor, S., \& Rezazadeh, A. (2019). The Investigation of Time Varying Efficiency in Financial Markets of Iran: Case Study of Foreign Exchange and Gold Markets. Financial Research Journal. https://doi.org/10.22059/frj.2019.272213.1006790

Morales, L., \& Gassie, E. (2014). Structural breaks and financial volatility: lessons from the BRIC countries. Economics, Management and Financial Markets.

Naeem, M. A., Hasan, M., Arif, M., Balli, F., \& Shahzad, S. J. H. (2020). Time and frequency domain quantile coherence of emerging stock markets with gold and oil prices. Physica A: Statistical Mechanics and Its Applications. https://doi.org/10.1016/j.physa.2020.124235

Perron, P., \& Phillips, P. C. B. (1988). Testing for a Unit Root in a Time Series Regression. Biometrika, 2(75), 335-346. https://doi.org/10.1080/07350015.1992.10509923

Sheik, M. M., \& Banu, M. A. S. (2015). Study on Weak-Form Efficiency of Foreign Exchange Markets of Developing Economies: Some India Evidence. International Journal of Management.

Siddiqui, S., \& Roy, P. (2019). Predicting volatility and dynamic relation between stock market, exchange rate and select commodities. Acta Universitatis Agriculturae et Silviculturae Mendelianae Brunensis. https://doi.org/10.11118/actaun201967061597 
Tursoy, T., \& Faisal, F. (2018). The impact of gold and crude oil prices on stock market in Turkey: Empirical evidences from ARDL bounds test and combined cointegration. Resources Policy. https://doi.org/10.1016/j.resourpol.2017.10.014

Yamaka, W., \& Maneejuk, P. (2020). Analyzing the causality and dependence between gold shocks and Asian emerging stock markets: A smooth transition copula approach. Mathematics. https://doi.org/10.3390/math8010120

Yarovaya, L., \& Lau, M. C. K. (2016). Stock market comovements around the Global Financial Crisis: Evidence from the UK, BRICS and MIST markets. Research in International Business and Finance, 37, 605-619. https://doi.org/10.1016/j.ribaf.2016.01.023

Attachment A:

Null Hypothesis: Unit root (common unit root process)

Method

Levin, Lin \& Chu t*

Statistic $-36.1140$

** Probabilities are computed assuming asymptotic normality Intermediate results on UNTITLED

\begin{tabular}{|c|c|c|c|c|c|c|c|}
\hline & 2nd Stage & Variance & HAC of & & Max & Band- & \\
\hline Series & Coefficient & of Reg & Dep. & Lag & Lag & width & Obs \\
\hline DAX 30 & -0.86834 & 0.0003 & 0.0001 & 1 & 17 & 4.0 & 412 \\
\hline DOW JONES & -0.91109 & 0.0003 & 4.E-05 & 6 & 17 & 16.0 & 407 \\
\hline CAC 40 & -0.86010 & 0.0003 & 0.0005 & 1 & 17 & 0.0 & 412 \\
\hline FTSE 100 & -0.95483 & 0.0002 & 3.E-05 & 7 & 17 & 11.0 & 406 \\
\hline FTSE MIB & -0.87840 & 0.0003 & 0.0001 & 1 & 17 & 5.0 & 412 \\
\hline GOLD & -0.97380 & 9.E-05 & 2.E-06 & 0 & 17 & 107.0 & 413 \\
\hline HANG SENG & -1.04163 & 0.0002 & 2.E-05 & 0 & 17 & 20.0 & 413 \\
\hline NIKKEI 225 & -0.82111 & 0.0002 & 5.E-06 & 1 & 17 & 73.0 & 412 \\
\hline SHANGHAI & -0.98287 & 0.0002 & 9.E-06 & 0 & 17 & 34.0 & 413 \\
\hline SILVER & -1.01008 & 0.0004 & 5.E-05 & 3 & 17 & 16.0 & 410 \\
\hline & Coefficient & t-Stat & SE Reg & $\mathrm{mu}^{*}$ & sig* & & Obs \\
\hline Pooled & -0.94505 & -45.506 & 1.002 & -0.500 & 0.707 & & 4110 \\
\hline
\end{tabular}

Source: Own elaboration.

Attachment B:

Null Hypothesis: Unit root (individual unit root process)

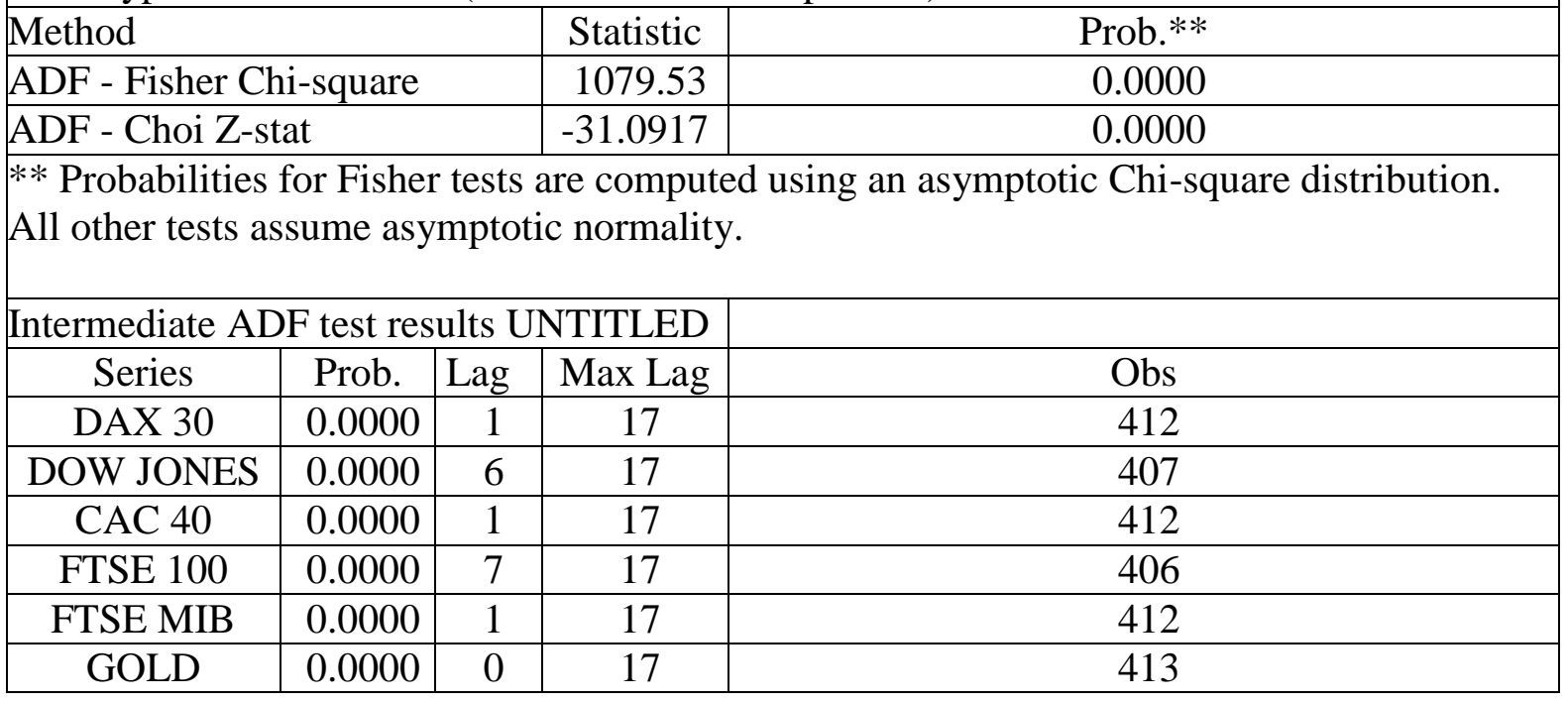




\begin{tabular}{|c|c|c|c|c|}
\hline HANG SENG & 0.0000 & 0 & 17 & 413 \\
\hline NIKKEI 225 & 0.0000 & 1 & 17 & 412 \\
\hline SHANGHAI & 0.0000 & 0 & 17 & 413 \\
\hline SILVER & 0.0000 & 3 & 17 & 410 \\
\hline
\end{tabular}

Source: Own elaboration.

Attachment C:

Null Hypothesis: Unit root (individual unit root process)

Method

PP - Fisher Chi-square

PP - Choi Z-stat

Statistic

1559.15

$-38.5919$

Prob.**

** Probabilities for Fisher tests are computed using an asymptotic Chi-square distribution.

All other tests assume asymptotic normality.

Intermediate Phillips-Perron test results UNTITLED

\begin{tabular}{|c|c|c|c|}
\hline Series & Prob. & Bandwidth & Obs \\
\hline DAX 30 & 0.0000 & 9.0 & 413 \\
\hline DOW JONES & 0.0000 & 5.0 & 413 \\
\hline CAC 40 & 0.0000 & 8.0 & 413 \\
\hline FTSE 100 & 0.0000 & 7.0 & 413 \\
\hline FTSE MIB & 0.0000 & 10.0 & 413 \\
\hline GOLD & 0.0000 & 18.0 & 413 \\
\hline HANG SENG & 0.0000 & 3.0 & 413 \\
\hline NIKKEI 225 & 0.0000 & 1.0 & 413 \\
\hline SHANGHAI & 0.0000 & 1.0 & 413 \\
\hline SILVER & 0.0000 & 7.0 & 413 \\
\hline
\end{tabular}

Source: Own elaboration. 